Ĭgdır Üniversitesi Fen Bilimleri Enstitüsü Dergisi, 11(Özel Sayı): 3496-3506, 2021

Journal of the Institute of Science and Technology, 11(Special Issue): 3496-3506, 2021

\begin{tabular}{cr}
\hline Moleküler Biyoloji ve Genetik / Moleculer Biology and Genetic & DOI: 10.21597/jist.1029010 \\
Geliş tarihi / Received: 27.11 .2021 & Araştırma Makalesi / Research Article \\
\hline
\end{tabular}

ISSN: 2146-0574, eISSN: 2536-4618

Atıf İçin: Aydin A, Eren Ö, 2021. Bazı Tef Genotiplerinde RAPD MArkırları Kullanılarak Genetik Varyasyonun Belirlenmesi. Iğdır Üniversitesi Fen Bilimleri Enstitüsü Dergisi, 11(Özel Sayı): 3496-3506.

To Cite: Aydin A, Eren Ö, 2021. Determination of Genetic Variation in Some Teff Genotypes Using RAPD Markers. Journal of the Institute of Science and Technology, 11(Special Issue): 3496-3506.

\title{
Bazı Tef Genotiplerinde RAPD Markırları Kullanılarak Genetik Varyasyonun Belirlenmesi
}

\section{Adnan AYDIN ${ }^{1 *}$, Eren ÖZDEN ${ }^{2}$}

ÖZET: Günümüzde tüketici bilincinin artması sonucu sağlıklı gıda ürünlerine talep her geçen gün artmaktadır. Kimyasal bileşimi ve beslenme özelliklere sahip olan Tef bitkisi, insan beslenmesinde geçmişten beri kullanılan bir bitki olmakla beraber, ülkemizde de alternatif olarak yetiştirilebilecek kaynaklardan biridir. Sağlıklı yaşam açısından son derece önemli bir tahıl olan tef, glutensiz olması nedeniyle de özellikle çölyak hastalarının beslenmesinde önemli yer tutar. Bunun yanında yetişme koşullarının zor olmaması ve hasat süresinin kısa olmasıyla beraber gelecekte kuraklığa kolayca uyum sağlayabileceği düşüncesi tef tahılının değerini her geçen gün arttırmaktadır. Çalışma kapsamında Et 2016 tef bitkisi kullanılarak 19 RAPD markırı ile taranmıştır. İyi amplikon veren 10 tane RAPD primeri ile Tef bitkisinde genetik varyasyon araştırması yapılmıştır. Kullanılan 10 tane RAPD primeri ile PZR sonrası agaroz jel elektroforez yöntemi ile amplikonların ayrıştırılması sağlanarak varlık (1) ve yokluk (0) skorlaması gerçekleştirilmiştir. Elde edilen verilere ile Jaccard benzerlik indeksi kullanılarak temel koordinat analizi ve Bayesian istatistiği ile genotipler arasında dendogram oluşturulmuştur. Yapılan analizler sonucunda genotipler arasındaki genetik varyasyonun düşük olduğu saptanmıştır. Zobel Basic ve Dega Basic genotiplerinde çok az düzeyde farklılık tespit edilmiş olup, daha çok markır ile teyit edilmesi gerekmektedir. Sonuç olarak bu genotipler arasındaki varyasyonun artırılması için farklı yaklaşımlar kullanılarak (mutajenler vb.) varyasyonun artırılması önerilmektedir.

Anahtar Kelimeler: Eragrostis tef, Moleküler Markırlar, Çeşitlilik

\section{Determination of Genetic Variation in Some Teff Genotypes Using RAPD Markers}

ABSTRACT: As a result of increasing consumer awareness, the demand for healthy food products is increasing day by day. Teff, which has chemical composition and nutritional properties, is a plant that has been used in human nutrition since the past, and it is one of the sources that can be grown as an alternative in our country. Being a very important grain for a healthy life, teff has an important place in the diet of celiac patients because it is gluten-free. Besides, the fact that the growing conditions are not difficult and the harvest period is short, the thought that it can easily adapt to drought in the future increases the value of teff grain day by day. Within the scope of the study, 19 RAPD markers were screened using Et 2016 genotip. Genetic variation research was conducted in Teff plant with 10 RAPD primers giving good amplicon. Presence (1) and absence (0) scoring were performed by separating amplicons using agarose gel electrophoresis method after PCR with 10 RAPD primers used. By using the Jaccard similarity index with the data obtained, a dendogram was created between the genotypes with the basic coordinate analysis and Bayesian statistics. As a result of the analysis, it was determined that the genetic variation between the genotypes was low. Very little difference was detected in Zobel Basic and Dega Basic genotypes and needs to be confirmed with more markers. As a result, it is recommended to increase the variation by using different approaches (mutagens, UV, etc.) to increase the variation among these genotypes.

Keywords: Eragrostis tef, Molecular Markers, Diversity

\footnotetext{
${ }^{1}$ Adnan AYDIN (Orcid ID: 0000-0002-8284-3751), Iğdır Üniversitesi, Ziraat Fakültesi, Tarımsal Biyoteknoloji Bölümü, Iğdır, Türkiye

${ }^{2}$ Eren ÖZDEN (술ㅇ ID: 0000-0001-7507-9815), Iğdır Üniversitesi, Ziraat Fakültesi, Bahçe Bitkileri Bölümü, Iğdır, Türkiye

*Sorumlu Yazar/Corresponding Author: Adnan AYDIN, e-mail: aydinadnann@ gmail.com

15-17 Kasım 2021 tarihlerinde Iğdır'da düzenlenen “Uluslararası Katılımlı Türkiye 7. Tohumculuk Kongresi'nde” sözlü sunum olarak sunulmuştur.
} 


\section{GÍRIȘ}

Poaceae familyas1, Eragrostidae tak1m1, Eragrostis cinsinde bulunan tef bitkisinin 350 türü olduğu rapor edilmektedir (Sarı ve Tiryaki, 2018). İlgili cins hem tek yıllık hem de çok yıllık karakterde türleri barındırmaktadır (Conert, 1992; Tefera ve ark., 2003). Erogrostif tef bitkisi eskiden Eragrostis abyssinica (Jacq.) ve Cynodon abyssinicus (Jacq.) gibi isimler ile bilinirken günümüzde Eragrostis tef (Zucc.) Trotter olarak sistematikte yerini almıştır (Assefa ve ark., 2011). Bitkinin taksonomideki sınıflandırılmasındaki bu belirsizliklerin en büyük nedeni Eragrostis cinsindeki türlerin poliploidy göstermesi, yani farklı kromozom sayılarına sahip türlerin varlığı ve kompleks bir genomun olmasından kaynaklanmaktadır. Temel kromozom sayısı 10 olan cins içerisinde farklı poliploidy seviyelerinde genom yapılarına sahip, auto- poliploid ve allo-poliploid yapı sergileyen çok sayıda tür bulunmaktadır. Eragrostis tef, allotetraploid $(2 \mathrm{n}=4 \mathrm{x}=40$ ) bir bitki olmasiyla bilinmektedir (Assefa ve ark., 2011). Tef'in kültürü yapılan ragi darısı (Eleusine coracana) ile en yakın ilişkili olduğu bitki türü olarak gösterilirken, alt familya olarak en yakın ilişkili kültür bitkileri olarak sorgum (Sorghum bicolor) ve mısır (Zea mays) gösterilmektedir (Sarı ve Tiryaki, 2018). Ortolog genler kullanılarak yapılan moleküler DNA dizi analizlerinin sonucunda ise tef bitkisine en yakın bitki türlerinin cin darı (Setaria italica) ve sorgum (Sorghum bicolor) olduğu rapor edilmiştir (Cannarozzi ve ark., 2014).

Cins içerisinde çok miktarda bitki topluluğu olmasına rağmen tanesi için yetiştiriciliği yapılan tek tür Erigrostis tef olarak bilinmektedir. Yaygın ismi tef olarak bilinen bitki 'Yazotu', 'aşkotu' olarak da bilinen glutensiz bir bitkidir. Dünyada en küçük tane boyutuna (1 mm'den küçük) sahip bir tahıl olma özelliğini korumaktadır (Geren ve ark., 2019). Bitkinin anavatanı Etiyopya'dır ve buğday gibi tanelerinin öğütülmesiyle elde edilen undan ekşi mayalı ekmek yapılmaktadır. Tef, tarımına başlanılan ilk bitkilerden biri olması ile MÖ 5000 yıllarında Etiyopya'nın yüksek yaylalarında tanesi için ve hayvan yemi olarak yetiştirildiği farklı araştırıcılar tarafından rapor edilmektedir (Eckhoff ve ark., 1993; Hickman ve ark., 2013; Geren ve ark., 2019). Tef bitkisinin alternatif bitki olarak görülmesi ve yaygın olmasının temel nedenlerinden bir tanesi de içinde gluten olmaması (Gebremariam ve ark., 2014) ya da çok düşük seviyede olmasından kaynaklanmaktadır (Mebratu ve ark., 2016). Tef bitkisinin tanesi, kinoa veya çia gibi buğdaya alternatif iyi bir gıda olması, insan vücudundaki hormon seviyelerini dengelediği, bağışıklık sistemini güçlendirdiği, sindirimin sisteminin uyarılmasına katkı sağladığı bildirilmektedir (Geren ve ark., 2019). Ayrıca en küçük taneli tahıl grubunda olmasına rağmen yüksek lifli bir yapıya sahip olması, protein, magnezyum, demir ve kalsiyum içeriğinin yüksek olması bu bitkinin alternatif bir tahıl bitkisi olarak yaygınlaşmasına olanak sağlamaktadır. İçinde barındırdığı vitamin-mineraller ile insanlarda sağlıklı bir şekilde kilo kaybını yapmakta ve kemikleri güçlendirmesi önemini daha da ortaya koymaktadır. Tanesinin içindeki demir vücudun önemli organlarında ve bölgelerindeki oksijenasyonu yani oksijene doymayı arttırmaktadır (Gebremariam ve ark., 2014). Tef bitkisinin biyotik ve abiyotik streslere olan dayanıklılığı ile tarımı kolay yapılabilecek bir bitki olması, diğer kültür bitkilerine göre daha ekonomik şartlarda yetiştirilecek bitki olması avantajları arasında bulunmaktadır (Geren ve ark., 2019). Ayrıca depolama koşullarında herhangi bir kimyasal kullanmadan bitkinin taneleri birkaç yıl canlılıklarını sürdürebilmektedir (Sarı ve Tiryaki, 2018).

Tef bitkisinin ülkemizde yeni bir bitki olması ve glutensiz olmasından kaynaklı alternatif bir tahıl grubu olarak akademik çalışmalarda araştırılmaya başlanmıştır (Kaya ve ark., 2020; Köten, 2021). Ülkemize farklı ülkelerden getirilmiş olan tef genotiplerinde varyasyonların ve genetik çeşitliliğinin belirlenmesi için moleküler çalışmalar ile bu genetik varyasyonun ortaya konulması ile yapılacak olan ıslah çalışmalarına büyük katkı sunacaktır. Bitki genetik kaynaklarındaki çeşitlilik ıslah çalışmaları için oldukça önemlidir. Bu sebeple bitki genotiplerin, genetik açıdan varyasyonun yüksek olması daha sonra 
yapılacak olan ıslah çalışmaları için iyi bir materyal olarak kullanılabilmesine olanak sağlayacaktır (Ulukan, 2011).

Bitki ıslahında temel başarı genotipler arasındaki genetik ilişki ve bitki grupları arasındaki genom farklılığından kaynaklanan genetik değişkenliklere bağlı olmaktadır (Rana ve Bhat, 2005; Abdellatif ve Soliman, 2013). Genetik farklılı; türlerin kendi içerisinde, türler arasında ve tüm ekosistemde; biyoçeşitlilik ve organizma çeşitliliği açısından önemli bir faktördür. Farklı özellikte çeşitler üretmek için ebeveyn seçimi sslah çalışmalarında büyük ölçüde geliştirilebilir. Farklı genoma sahip bitki gruplarını tanımlamak, bitki popülasyonun yapısını anlamak ve temel hat gruplarının birbirinden ayırt edilebilmesi için genetik çalışmalarda markırların kullanımı büyük önem taşımaktadır (Tyagi ve ark., 2014). Genetik çeşitlilik tahminleri soyağacı ve morfolojik veriler (Van Esbroeck ve ark., 1999), biyokimyasal markırlar (Wendel ve ark., 1992) ve DNA'ya dayalı moleküler markırlar (Yu ve ark., 2012) kullanılarak gerçekleştirilmektedir. Bu yaklaşım ile yapılan genetik çeşitlilik çalışmalarında morfolojik belirteçler yanıltıcı olabilmektedirler veya çalışmayı sınırlandırabilmektedir. Morfolojik belirteçler bitki gelişim aşamasında çevreden etkilendikleri için genom bilgisinin ortaya konulmasında yetersiz kalmaktadır (Lukonge ve ark., 2007). Bunun aksine moleküler markırlar, doğrudan allellik varyasyonu ölçebildikleri ve genetik uzaklık tahminlerini allel düzeyinde verebildikleri için güvenilirlikleri ve bilgi içerikleri daha gerçekçidir (Tyagi ve ark., 2014). Farklı genotiplerde genetik karakterizasyonun yapılması bitki ıslahı açısından çok önemlidir (Govindaraj ve ark., 2014). Bitki genetik kaynaklarındaki çeşitlilik, hem çiftçi hem sslahçı açısından istenilen karakterde yeni ve gelişmiş bitki çeşitleri üretilmesine olanak sağlar. DNA düzeyinde kullanılan moleküler markırlar genotipler arasındaki farklılıkları ortaya çıkardığı gibi genetik kaynakların karakterizasyonu için doğrudan kullanılan, daha güvenilir ve etkili bir yöntemdir. Genetik varyasyonların ortaya konulmasında kullanılan mevcut moleküler markırlar RFLP, PCR-RFLP, RAPD, ISSR, SSR gibi makırlar olup, daha kolay, daha ucuz ve daha hızlı oldukları için tercih edilmektedirler.

Bu çalışma kapsamında ülkemizde de alternatif bitki olarak görülmeye başlanan ve özellikle gluten içermeyen bir tahıl gurubunda bulunan ve Etiyopya'dan temin edilen 5 farklı tef bitkisinin genetik varyasyonun moleküler markırlar ile ortaya konulması hedeflenmiştir. Elde edilen verilerle ülkemizde tef bitkisinin ıslahına yönelik ön veriler elde edilmiş olup, sonraki çalışmalara katkı sağlayacağı düşünülmektedir.

\section{MATERYAL VE METOT}

\section{Bitki Materyali ve Yetiştirilmesi}

Çalışmada kullanılan bitki materyali Etiyopya kökenli olup genotipler Et 2016, Zobel Basic, Dega Basic, Dega CI, Boset Basic'dir. Kullanılan genotiplerin hepsi Erigrostis cinsine ait olan ve yetiştiriciliği yapılan tek tür olan Erigrostis tef türüne ait genotiplerdir. Tef bitkisine ait 5 (beş) farklı genotip ortalama $25^{\circ} \mathrm{C}$ 'de saksılarda yetiştirilmiş ve bitki boyu 5-7 santimetreye boyuna geldikten sonra DNA izolasyonu gerçekleştirmek amacıyla yaprakları steril bir şekilde toplanarak $-20^{\circ} \mathrm{C}$ 'de saklanmıştır.

\section{DNA izolasyonu ve kalite-miktarının belirlenmesi}

Streril koşullarda toplanmış yaprak örnekleri Aydin ve ark. (2018)'e göre modifiye edilerek gerçekleştirilmiştir. DNA kalite ve miktarının belirlenmesinde Nano-drop (Maestrogen, MN-913) ve Agaroz Jel Elektroforetik yöntemler kullanılarak belirlenmiş̧ir (Aydın, 2018). 


\section{Kullanılan DNA Moleküler Markırları}

Çalışmada toplam 19 RAPD primeri kullanılmıştır ve bir genotip ile taranan bütün primerlerden sadece en iyi amplikon verenler genetik varyasyonun belirlenmesinde kullanılmıştır. Çalışmada kullanılan RAPD primerleri Çizelge 1'de gösterilmektedir.

Çizelge 1. Çalışmada kullanılan RAPD primer dizileri.

\begin{tabular}{lll}
\hline NO & Primer ID & Primer sequence $\mathbf{5}^{\prime} \rightarrow \mathbf{3}^{\prime}$ \\
\hline $\mathbf{1}$ & OPA-05 & AGGGGTCTTG \\
$\mathbf{2}$ & OPA-06 & GGTCCCTGAC \\
$\mathbf{3}$ & OPB-12 & CCTTGACGCA \\
$\mathbf{4}$ & OPB-13 & TTCCCCCGCT \\
$\mathbf{5}$ & OPC-08 & TGGACCGGTG \\
$\mathbf{6}$ & OPC-09 & CTCACCGTCC \\
$\mathbf{7}$ & OPD-01 & ACCGCGAAGG \\
$\mathbf{8}$ & OPD-02 & GGACCCAACC \\
$\mathbf{9}$ & OPF-16 & GGAGTACTGG \\
$\mathbf{1 0}$ & OPF-17 & AACCCGGGAA \\
$\mathbf{1 1}$ & OPG-03 & GAGCCCTCCA \\
$\mathbf{1 2}$ & OPG-04 & AGCGTGTCTG \\
$\mathbf{1 3}$ & OPH-07 & CTGCATCGTG \\
$\mathbf{1 4}$ & OPH-10 & CCTACGTCAG \\
$\mathbf{1 5}$ & OPI-11 & ACATGCCGTG \\
$\mathbf{1 6}$ & OPI-14 & TGACGGCGGT \\
$\mathbf{1 7}$ & OPK-15 & CTCCTGCCAA \\
$\mathbf{1 8}$ & OPK-18 & CCTAGTCGAG \\
$\mathbf{1 9}$ & OPN-19 & GTCCGTACTG \\
\hline
\end{tabular}

Polimeraz Zincir Reaksiyonu (PZR) Çalışmaları

PZR çalışmalarında aşağıda Çizelge 2'de gösterildiği gibi kullanılan kimyasal ve miktarları gösterilmiştir.

Çizelge 2. PZR çalışmalarında kullanılan kimyasallar ve miktarları

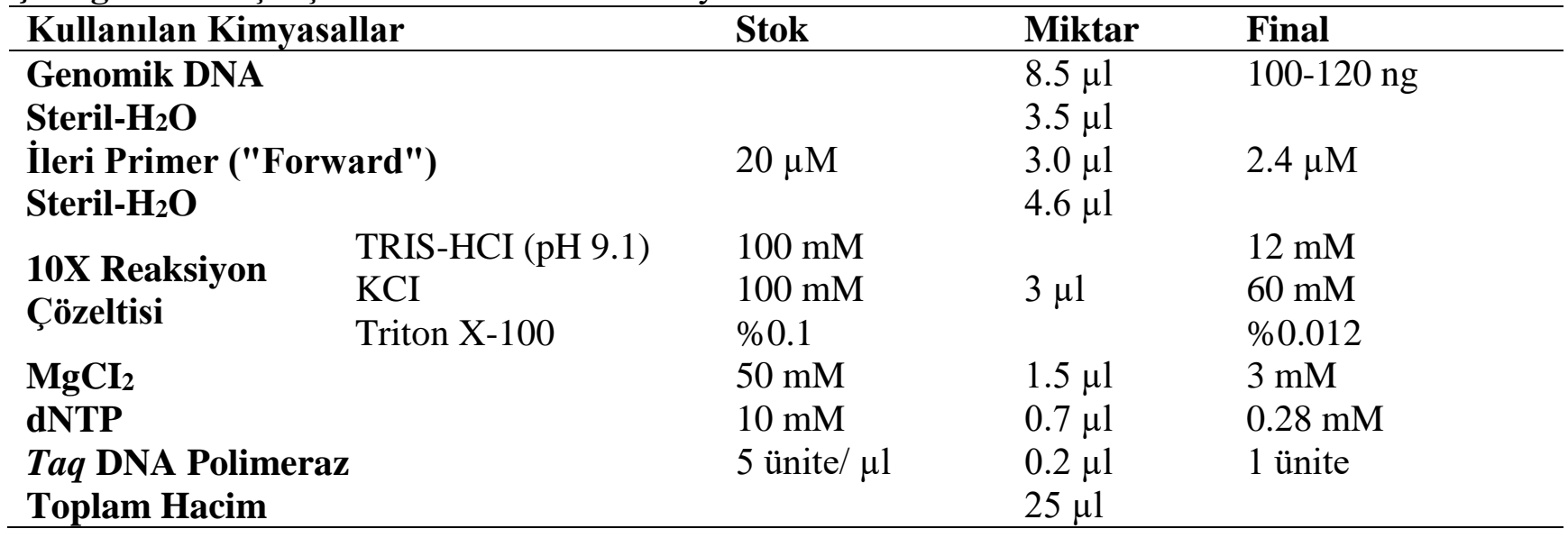

Kullanılan RAPD primerlerinin çoğaltımında PZR profili Çizelge 3'de belirtilmiş olup "TouchDown” PZR yöntemi kullanılmıştır (Karaca ve ark., 2019). 
Çizelge 3. Çalışmada kullanılan PZR profili

\begin{tabular}{lllll}
\hline PZR Profili & & Zaman & Döngü Sayısı & Aşama \\
\hline Hot Start & $94^{\circ} \mathrm{C}$ & 5 dakika & 1 döngü & Ön-denatürasyon \\
& $94^{\circ} \mathrm{C}$ & 1 dakika & & Denatürasyon \\
Ön PZR & $42^{\circ} \mathrm{C} \rightarrow 37^{\circ} \mathrm{C}$ & 1 dk $20 \mathrm{sn}$ & 10 döngü & Renatürasyon \\
& $72^{\circ} \mathrm{C}$ & 2 dakika & & Sentez \\
& $94^{\circ} \mathrm{C}$ & 2 dakika & & Denatürasyon \\
PZR & $37^{\circ} \mathrm{C}$ & $1 \mathrm{dk} 20 \mathrm{sn}$ & 30 döngü & Renatürasyon \\
& $72^{\circ} \mathrm{C}$ & 2 dakika & & Sentez \\
Final & $72^{\circ} \mathrm{C}$ & 10 dakika & 1 döngü & Final Sentez \\
& $4^{\circ} \mathrm{C}$ & 1 saat & & \\
\hline
\end{tabular}

\section{PZR ürünlerinin ayrıştırılması}

Agaroz jel elektroforez yöntemi kullanılarak örnekler arasındaki polimorfizim ortaya konulmuştur. Çalışmada kullanılan RAPD primerlerinin verdikleri amplikonlar \% 2.0 konsantrasyonda olan agaroz jel ile gerçekleştirilmiştir.

100 mL'lik Agarose Jel içine $5 \mu \mathrm{L}$ olacak şekilde RedSafe ${ }^{\mathrm{TM}}$ (INtRON BIOTECHNOLOGY, Cat.No. 21141) ilave edilmiştir. PZR örnekleri 1/6 örnek hacmi olacak şekilde 6x DNA yükleme çözeltisi ile karıştırılıp, örnekler jel kuyucuklarına yüklenmiş ve $1 \mathrm{X}$ TBE çözeltisi kullanılarak 5V/cm uygulanarak polimorfizimler yakalanana kadar jeller yürütülmüştür.

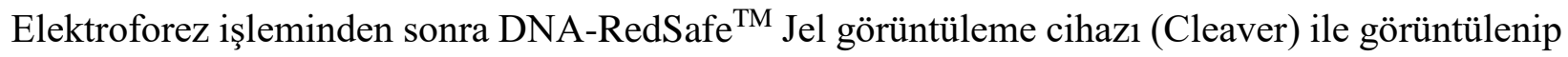
jel görüntüsü UVpro programı ile bilgisayar ortamında kaydedilmiş ve skorlama ve fotoğraflama aşamalarında kullanılmak üzere depolanmıştır (Aydın, 2018).

\section{Moleküler Veri Analizleri}

\section{a) Jellerin analiz edilmesi ve skorlamalar}

PZR sonucunda örnekler Jel Elektroforez Yöntemi kullanılarak belirtilen primerler tarafindan oluşan amplikonlar varlık durumunda bir (1), yokluk durumunda (0) olarak skorlamalar yapılmıştır.

\section{b) Polimorfizim bilgi içeriğinin belirlenmesi}

Her bir markır genotipler arasında oluşturmuş olduğu paterne göre Polimorfik Bilgi İçeriği ("Polymorphic Information Content" (PIC)) Smith ve ark., (1997) ye göre aşağıdaki formül ile hesaplanmıştır.

$$
P I C=1-\sum_{i}^{2}
$$

$\mathrm{fi}=\mathrm{i}$ markırının frekansı.

\section{c) Verilerin kümeleme analizleri}

Elde edilen varlık (1), yokluk (0) skorları, Jaccard'ın genetik benzerlik indeksleri ve kümeleme çalışmaların hesaplamasında kullanılmıştır. Kümeleme analizleri MrBayes programı ile Bayes istatistiği kullanılarak genotipler düzlemsel ilişkileri ortaya konmuştur.

\section{d) Temel konumlandırma analizi (PCoA)}

MVSP yazılım programı kullanılarak temel koordinat analizi ("Principal coordinate analyses" (PCoA)) ile çalışmada kullanılan tef genotipleri arasındaki konumsal ilişkileri ortaya konulmuştur. PCoA analizinin sonuçlandırılmasında Jaccard benzerlik indeksi kullanılarak gerçekleştirilmiştir. Jaccard benzerlik indeksinin formülü aşağıda gösterilmiştir.

$$
J c_{i j}=\frac{a}{(a+b+c)}
$$

$\mathrm{i}, \mathrm{j}$, farklı örnekler, örneğin iki pamuk çeşidi

$\mathrm{a}=\mathrm{i}$ ve $\mathrm{j}$ örneğindeki varlık skorlarının sayısı (1)

$b=i$ örneğindeki varlık skorlarının sayısı (1) j örneğindeki yokluk skorlarının sayısı (0) 


\section{BULGULAR VE TARTIŞMA}

Çalışmada Etiyopya'dan temin edilmiş 5 farklı genotip ile çalışmalar yapılmıştır. Kullanılan genotiplerin genetik varyasyonunun belirlenmesi için genotiplere ait tohumlar uygun sicaklık ve nem ortamında ekilerek bitkiler 5-7 cm boyuna geldikten sonra yapraklar steril bir şekilde toplanarak DNA izolasyonu için $-20{ }^{\circ} \mathrm{C}$ 'de muhafaza edilmiştir. DNA izolasyonu Aydin ve ark., (2018)'e göre motife edilerek gerçekleştirilmiştir. Şekil 1'de görüldüğü üzere izolasyonu yapılan genomik DNA'lar görülmekte ve polisakkarit, protein ve fenolik bileşiklerden arındırılmış olduğu saptanmıştır. Ayrıca her kuyucuğa 200-300 ng olacak şekilde $8 \mu \mathrm{L}$ gDNA ve $2 \mu \mathrm{L}$ yükleme bufferı ile karıştırılarak \%1 agaroz jelde yaklaşık bir saat yürütülmüştür.

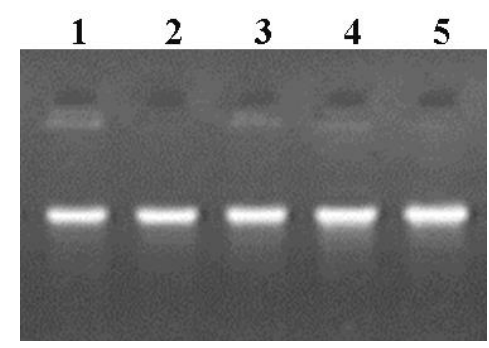

Şekil 1. gDNA Jel görüntüsü (1-Et 2016, 2-Zobel Basic, 3-Dega Basic, 4-Dega CI, 5-Boset Basic)

DNA kalite ve miktarlarının belirlenmesinde nano-drop ve agaroz jel elektroforetik yöntemler kullanılmıştır. DNA'nın protein, polisakkarit ve fenolik bileşiklerden arındırılğını Çizelge 4'te de

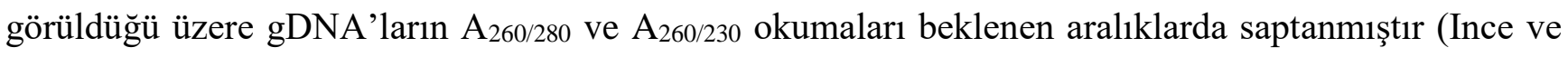
Karaca, 2009). Ayrıca gDNA miktarı olarak $\mu$ L'sindeki ng 96 ile150 arasında bulunmuş olup PZR çalışmaları için yeterli miktar elde edilmiştir.

Çizelge 4. Nano-Drop sonuçlarına göre kalite ve miktarının belirlenmesi

\begin{tabular}{llll}
\hline Genotip & $\mathbf{A 2 6 0 / 2 8 0}$ & $\mathbf{A 2 6 0 / 2 3 0}$ & $\mathbf{n g} / \boldsymbol{\mu L}$ \\
\hline Et 2016 & 1,85 & 1,02 & 150 \\
Zobel Basic & 1,80 & 1,30 & 108 \\
Dega Basic & 1,84 & 1,15 & 96 \\
Dega CI & 1,88 & 1,21 & 105 \\
Boset Basic & 1,86 & 1,09 & 124 \\
\hline
\end{tabular}

\section{Jellerin Analiz Edilmesi ve Primerlerin PIC Değerlerinin Belirlenmesi}

Elde edilen gDNA'ların kaletisinin ve miktarının yeterli olması ile Et 2016 genotipi kullanılarak toplamda 19 tane RAPD primeri ile taranmıştır. Bu primerlerden en iyi amplikon veren 10 tane RAPD primeri tef bitkisinin genetik varyasyonunun belirlenmesinde kullanılmıştır (Çizelge 5). PZR sonrası oluşmuş olan amplikonlar \%2 agaroz jel elektroforezde amplikonlar iyice ayrışana kadar jeller yürütülmüştür. Polimorfik bantlar kesin olarak ayrıştıktan sonra varlık (1) ve yokluk (0) skorlaması gerçekleştirilmiştir. Yapılan bütün analizler genotipler arasındaki varlık ve yokluk skorlamarına göre yapılmıştır.

En iyi amplikon veren 10 primerden sadece 2 tanesinde polimorfizim saptanmıştır. Geri kalan 8 tanesinde ise herhangi bir polimorfizim belirlenmemiştir. Primerlerin kullanılan genotiplerdeki PIC değerleri 0-0,320 arasında değişmiştir. 0,320 PIC değeri veren primerler ise OPA-05 ile OPC-09 primerleridir. Patern sayısı da yine 1-2 arasında değişmiş olup, 2 farklı patern veren primerler PIC değeri 0,320 olan primerler olarak saptanmıştır. Kullanılan primerde allel sayıları ise 2-9 arasında değişmiş ve ortalama allel sayısı 5,4 olarak hesaplanmıştır. En fazla allel sayısı 9 ile OPB-12 primeri iken en az allel sayısı 2 ile OPI-14 primeri olarak gözlemlenmiştir. Çalışmada kullanılan primerlerden sadece OPA-05 ile OPC-09 farklı yani polimorfik amplikonları ortaya koyduğundan sadece bu iki primerin varlığında 
çok az da olsa varyasyon saptanmıştır. Örneğin OPC-09 RAPD primeri sadece Zobel Basic genotipinde tek bir allel farklılığından kaynaklanan bir varyasyon göstermiştir (Şekil 2). Buna karşın OPB-12 ve OPB-13 RAPD primerleri sırasıyla 9 ve 6 allel oluşturmuş olmalarına rağmen herhangi bir polimorfizim tespit edilmediği Şekil 2'de de görülebilmektedir.

Çizelge 5. Primerlerin polimorfizim bilgi içeriği

\begin{tabular}{llll}
\hline Primer & PIC & Patern Sayisı & Allel Sayıs \\
\hline OPA-05 & 0,32 & 2 & 7 \\
OPA-06 & 0 & 1 & 5 \\
OPB-12 & 0 & 1 & 9 \\
OPB-13 & 0 & 1 & 6 \\
OPC-09 & 0,32 & 2 & 5 \\
OPG-03 & 0 & 1 & 4 \\
OPG-04 & 0 & 1 & 6 \\
OPI-11 & 0 & 1 & 7 \\
OPI-14 & 0 & 1 & 2 \\
OPK-15 & 0 & 1 & 3 \\
\hline
\end{tabular}

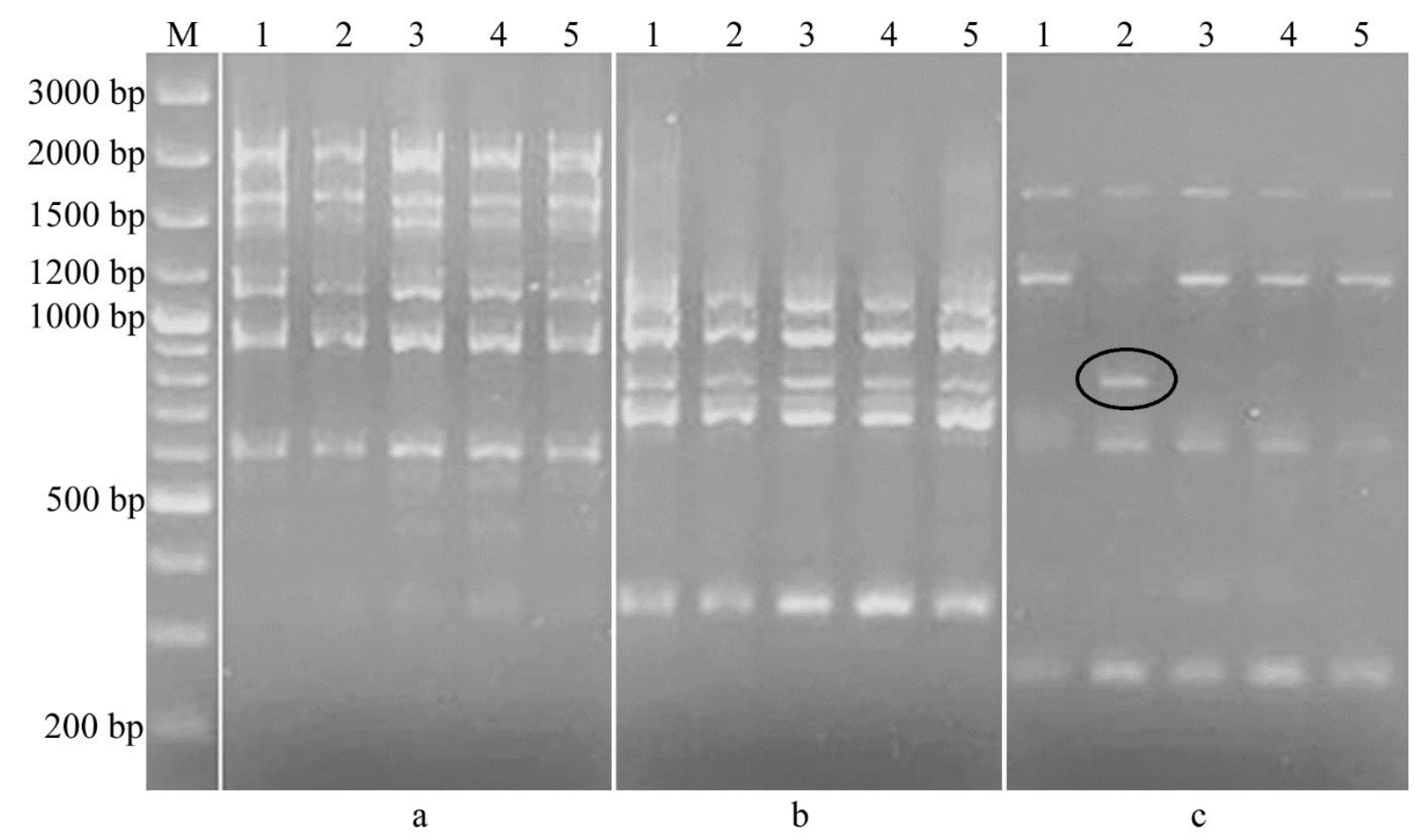

Şekil 2. OPB-12, OPB-13 ve OPC-09 RAPD Primerlerinin Jel Elektroforez Görüntüsü.

(1-Et 2016, 2-Zobel Basic, 3-Dega Basic, 4-Dega CI, 5-Boset Basic. a)-OPB-12, b)-OPB- 13, c)-OPC-09)

\section{Temel Konumlandırma Analizi (PCoA)}

PCoA analizi için Jaccard benzerlik indeksi ile çalışmada kullanılan primerlerin PZR sonrası oluşturmuş olduğu amplikonların varlık ve yokluk skorlaması kullanılarak elde edilmiştir. Bu analizin gerçekleştirilmesinde Çok Değişkenli İstatistik Paket ("Multi-Variate Statistical Package"-(MVSP)) programı kullanılarak Şekil 3'teki PCoA görseli elde edilmiştir. Çalışmada kullanılan beş farklı genotipten sadece iki tanesi farklı bölgelerde konumlanmış ve bu genotipler Zobel Basic ile Dega Basic genotipleridir. Diğer 3 genotip ise aynı noktada konumlanmıştır. Burada gerçekleşen analiz sonucunda bu farklılı̆̆ın temel nedeni polimorfizim bilgi içerikleri farklı olan OPA-05 ile OPC-09 RAPD primerlerindeki farklı allellerin Zobel Basic ve Dega Basic genotiplerinde ortaya çıkmasından kaynaklanmaktadır. Diğer üç genotipte ise (Et 2016, Dega CI, Boset Basic) kullanılan her 10 RAPD 
primerleri yönünden herhangi bir polimorfizimin tespit edilememesinden dolayı tek bir noktada ve aralarında herhangi bir farklılık tespit edilememiştir. Türlerdeki çeşitlilik zenginliği, farklı tarımsal ekolojiler, mahsul sistemleri ve amaçlara uygun çeşitler geliştirmek için mahsulün genetik olarak iyileştirilmesi için geniş firsatlar sunar (Tadesse ve ark., 2021). Bu gerçek nedeniyle, geçmişte farklı yaklaşımlar kullanarak tef germplazm koleksiyonlarındaki genetik çeşitliliği değerlendirmek ve ölçmek için çaba sarf edilmiştir (Assefa ve ark., 2017). Moleküler markırların genetik çeşitliliği belirlemede kullanılması son derece önemlidir.

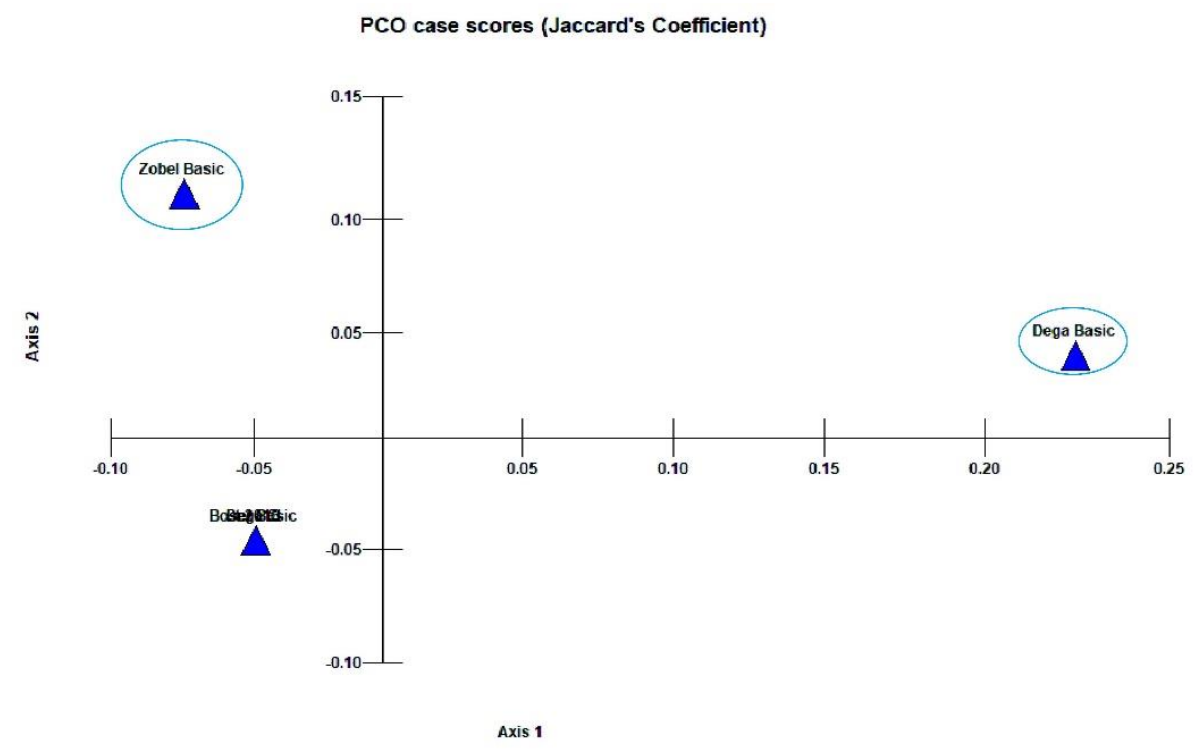

Şekil 3. Temel Koordinat Analizi (PCoA)

\section{Genotiplerin Kümeleme Analizleri}

MrBayes programı geniş bir filogenetik ve evrimsel model alanında "Bayesian" istatistiğinde "post probablity" (Ardıl Olasılık) tahminlerini de analizde kullanarak genotipler arasındaki en iyi ilişkiyi ortaya koyan bir programdır. Bu yöntemde analizler olasılığı en yüksek olan bir (a prior) topoloji ile başlar ve ağaçlar Markov Zinciri Monte Carlo (MCMC) yöntemi kullanılarak simüle edilir ve en iyi topolojiler yakalanarak sonraki olasılıkları yüksek olan ağaç/ağaçlar seçilmektedir (İnal, 2011). Filogenetik ağaçların sonraki olasılı̆̆ı analitik olarak belirlenmesi zordur. Bunun yerine, MCMC, "posterior” dağılımından örnekler çizerek oluşturulan ağaç ile veriler kullanılarak sonraki olasılık hesabı ortaya koymaktadır.

MrBayes programı kullanılarak varlık ve yokluk skorları ile analiz gerçekleştirilmiştir. Bu analiz sonucunda bölünmüş frekansın ortalama standart sapması 0.001109 olarak tespit edilmiştir. Bu şekilde ortalama standart sapmasının düşük olması bu analizin güvenilir olduğu anlamına gelmektedir. Yapılan bu analiz ile oluşturulmuş olan kümeleme analizi (filogenetik ağaç) iki kümeye ayrılmıştır. Dega Basic farklı bir kümede gösterilirken diğer dört genotip ise ayrı bir kümede ve bir arada toplanmıştır. Şekil 4 'te yeşil renkle çizilmiş olan kümedeki dört genotip arasında Zobel Basic genotipi diğer üç genotipe göre farklı bir dal uzunluğu ile farkını ortaya koymaktadır. Çalışmada elde edilen ağaç polar ağaç formatında Şekil 4'te gösterilmiştir. Moleküler markır teknolojisinin kullanımı, tahıl ekinlerinin geleneksel yetiştirme stratejilerini geliştirmek için çok çeşitli yeni yaklaşımlar sunmaktadır. Genel olarak, moleküler markır teknolojisinin tef sslahında kullanımı 10-15 yılı bulmaktadır (Assefa ve ark., 2011). Bununla birlikte, geleneksel tef ıslahını tamamlamak ve hızlandırmak için moleküler tekniklerin ve biyoteknolojik araçların kullanımına yönelik ön koşulların geliştirilmesine yönelik önemlidir. Yaptığımız çalışmada da ülkemizde tanınmaya başlayan tef bitkisinin ıslah çalışmalarında kullanımın 
daha verimli olabilmesi için moleküler çalışmalar elzem olmaktadır. Bu çalışmanın sonuçlarında elimizde mevcut tef genotiplerinin varyasyonun artırılması gerekmektedir.

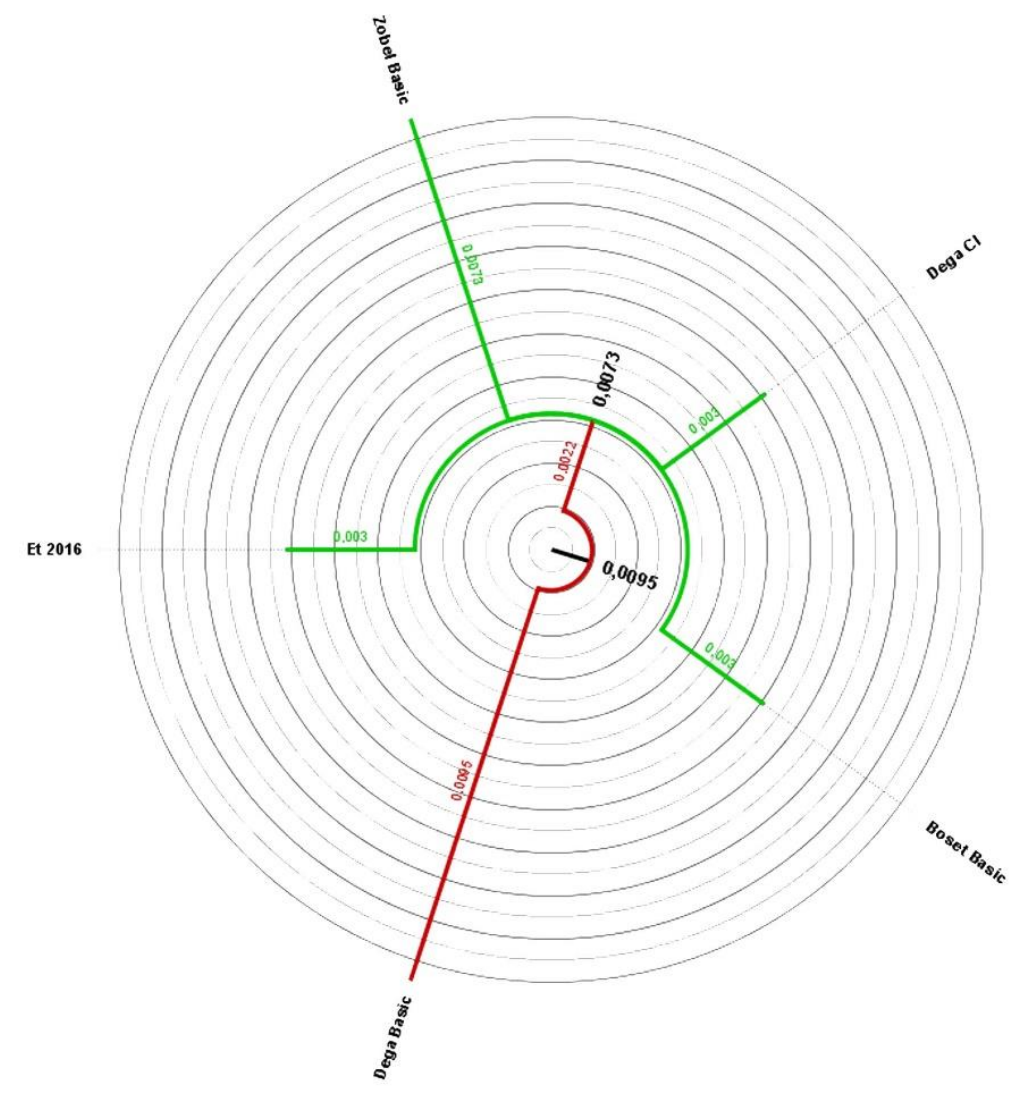

$\overline{0.001}$

Şekil 4. Çalışmada kullanılan tef genotiplerinin Bayes istatistiğiyle oluşturulmuş konsensus ağacı. Ağacın altındaki bar değeri baz değişim skalasını göstermektedir.

\section{SONUÇ}

Yapıla bu ön çalışma ile alternatif bitki olarak ülkemizde de kullanılmaya başlanan tef' in genetik varyasyonunun belirlenmesi hedeflenmiştir. Bu bağlamda Etiyopya'dan temin edilen beş farklı tef genotipi ile 19 RAPD markırı kullanılarak, farklı istatistik programları ile varyasyon ve genetik ilişkiler belirlenmiştir. Yapılan çalışmalar doğrultusunda 19 RAPD primerinden 10 tanesinin iyi amplikon vermesinden dolayı çalışmaya devam edilmiştir. 10 RAPD primerinden sadece iki tanesi (OPA-05 ile OPC-09) farklı allel oluşturmuş ve bu allellerden kaynaklı olarak az da olsa genetik varyasyon tespit edilmiştir. Geri kalan diğer sekiz primerde ise herhangi bir allell-lokus farklılığı tespit edilmemiştir. Elde edilen verilerin kullanılmasıyla ortaya konan bulgular değerlendirildiğinde sadece Zobel Basic ve Dega Basic genotiplerinde çok az bir genetik varyasyon saptanmıştır. Varyasyonun çok az olmasından dolayı da genetik varyasyonun daha iyi ortaya konması için farklı markır teknikleri ya da daha fazla markır ile taranması gerekmektedir. Çünkü çalışmamızda kullandığımız markırlar genomun sadece belli bir kısmını temsil etmektedir. Genetik varyasyonun net olarak ortaya konması için genomu temsil edecek bölgelerin daha fazla olması gerekmektedir. Ayrıca bu genotipler ıslah çalışmalarında kullanılacaksa varyasyonun artırılması için bitkilerde varyasyonu artıracak mutajenlerin kullanılması ile bitki genomunda mutasyonların oluşturulması önerilmektedir. 


\section{TEȘEKKÜR}

Çalışma materyalini bize gönderdiği için Etiyopya Wolla Üniversitesinden Dr. Seid Hussen Muhie'ye teşekkür ederiz.

\section{Çıkar Çatışması}

Makale yazarları aralarında herhangi bir çıkar çatışması yoktur.

\section{Yazar Katkısı}

Yazarlar makaleye eşit oranda katkı sağlamıştır.

\section{KAYNAKLAR}

Abdellatif KF, Soliman YA, 2013. Genetic Relationships of Cotton (Gossypium barbadense L.) Genotypes as Studied by Morphological and Molecular Markers. African Journal of Biotechnology, 12: 4736-4746.

Assefa K, Chanyalew S, Tadele Z, 2017. "Tef Eragrostis tef (Zucc.) Trotter Millets and Sorghum," in Biology and Genetic Improvement, J. V. Patil, Ed., 2017 John Wiley \& Sons Ltd. Published by John Wiley \& Sons Ltd, First edition.

Assefa K, Yu JK, Zeid M, Belay G, Tefera H, Sorrells ME, 2011. Breeding tef [Eragrostis tef (Zucc.) trotter]: conventional and molecular approaches. Plant Breeding, doi:10.1111/j.14390523.2010.01782.x

Aydın, 2018.Türkiye'de Tescillenmiş Bazı Ticari Pamuk Çeşitlerinin Moleküler Karakterizasyonu Üzerine Bir Araştırma. Akdeniz Üniversitesi Doktora Tezi.

Aydin A, Ince AG, Uygur Gocer E, Karaca M, 2018. Single Cotton Seed DNA Extraction without the Use of Enzymes and Liquid Nitrogen. Fresenius Environmental Bulletin, 27: 6722-6726.

Conert HJ, 1992. Eragrostoideae. in Hegi G (Ed.) Illustriert Flora von Mittel-Europa. Band. I, Vol. 3. Spermatophyta: Angiospermae: Monocotyledones 1(2) Poaceae (Parey Buchverlag: Berlin). Pp. 75-120.

Eckhoff JLA, Wichman DM, Scheetz J, Majerus M, Welty LE, Stallknecht GF, Ditterline RL, Dunn RL, Sands DC, 1993. Teff: a potential forage and grain crop for Montana. Montana AgResearch, 10:38-41.

Gebremariam MM, Zarnkow M, Becker T, 2014. Teff (Eragrostis tef) as a raw material for malting, brewing and manufacturing of gluten-free foods and beverages: a review, Journal of Food Science and Technology, 51(11):2881-2895.

Geren H, Kavut YT, Kir B, 2019. Effect of Different Row Spacings on the Yield and Some Yield Characteristics of Teff (Eragrostis tef) Crop Grown under Söke Ecological Conditions, Ege Üniversitesi Ziraat Fakültesi Dergisi, 56 (2):231-239.

Govindaraj M, Vetriventhan M, Srinivasan M, 2014, Importance of Genetic Diversity Assessment in Crop Plants and Its Recent Advances: An Overview of Its Analytical Perspectives Genetics Research International, 31487.

Hickman AL, Abaye OA, McCann MA, McCann JS, 2013. Acceptability and nutritional value of the teff grass for grazing horses, Journal of Equine Veterinary Science, 33:321-399.

Ince AG, Karaca M, 2009. The MAGi RNA extraction method: a highly efficient and simple procedure for fresh and dry plant tissues. Journal of the Science of Food and Agriculture, 89: 168-176.

İnal B, 2011. Bitki Moleküler Filogenisinde Kullanılan Bazı Gen ve Metodların Karşılaştırılması. Akdeniz Üniversitesi Yüksek Lisans Tezi. 
Karaca M, Aydin A, Ince, AG, 2019. Cytosine methylation polymorphisms in cotton using TD-MSRAPD-PCR. Modern Phytomorphology, 13: 13-19.

Kaya C, Tiryaki I, Sari U, Tuna M, 2020. Genetic relationship and nuclear dna content variation in Tef [Eragrostis tef (Zucc.) Trotter] accessions. Molecular Biology Reports, 47: 4455-4463.

Köten M, 2021. Development of tef [Eragrostis tef (Zucc.) Trotter] based gluten-free tarhana. Journal of Food Processing and Preservation, 45(1), e15133.

Lukonge E, Herselman L, Labuschangne MT, 2007. Genetic Diversity of Tanzanian Cotton (Gossypium hirsutum L.) revealed by AFLP analysis. African Journal Crop Science, 8: 773-776.

Mebratu Y, Raghavaiah CV, Ashagre H, 2016. Production potential of tef (Eragrostis tef (Zucc.) Trotter) genotypes in relation to integrated nutrient management on vertisols of mid high lands of Oromia Region of Ethiopia, East Africa. Adv. Crop Sci. Tech. 4:249.

Rana MK, Bhat KV, 2005. RAPD Marker for Genetic Diversity Study Among Indian Cotton Cultivars. Current Science, 88, 1956-1961.

Sarı U, Tiryaki İ, 2018. Alternatif Tahıl: Eskinin Unutulmuş Yeni Bitkisi Tef (Eragrostis tef [Zucc.] Trotter). KSÜ Tarim ve Doğa Derg 21(3). 447-456. DOI:10.18016/ ksudobil.328540

Smith JSC, Chin ECL, Shu H, Smith OS, Wall SJ, Senior ML, Mitchell SE, Kresovich S, Ziegle J, 1997. An evaluation of the utility of SSR loci as molecular markers in maize (Zea mays L.): comparisons with data from RFLPs and pedigree. Theoretical and Applied Genetics 95: 163-173.

Tadesse M, Kebede M, Girma D, 2021. Genetic Diversity of Tef [Eragrostis tef (Zucc.)Trotter] as Revealed by Microsatellite Markers. https://doi.org/10.1155/2021/6672397.

Tyagi P, Gore MA, Bowman DT, Campbell BT, Udall JA, Kuraparthy V, 2014. Genetic Diversity and Population Structure in the US Upland Cotton (Gossypium hirsutum L.). Theoretical Applied Genetics, 127: 283-295.

Ulukan H, 2011. The use of plant genetic resources and biodiversity in classical plant breeding. Acta Agriculturae Scandinavica, Section B - Plant Soil Science, 61 (2), 97-104.

Van Esbroeck GA, Bowman DT, May OL, Calhoun DS, 1999. Genetic Similarity Indices for Ancestral Cotton Cultivars and Their Impact on Genetic Diversity Estimates of Modern Cultivars. Crop Science, 39: 323-328.

Wendel JF, Brubaker CL, Percival AE, 1992. Genetic Diversity in Gossypium hirsutum L. and the Origin of Upland cotton. American Journal of Botany, 79: 1291-1310.

Yu JZ, Fang DD, Kohel RJ, Ulloa M, Hinze LL, Percy RG, Zhang J, Chee P, Scheffler BE, Jones DC, 2012. Development of a Core Set of SSR Markers for the Characterization of Gossypium Germplasm. Euphytica, 187: 203-213. 